\title{
PARADIGM SPACE OF MODERN HIGHER EDUCATION IN UKRAINE
}

\author{
VIKTORIYA ZHELANOVA
}

\begin{abstract}
The article analyzes the paradigm space of higher education in Ukraine. It is proved that the modern education paradigm has a synthetic character, is based on the polyparadigmality principles and is a synthesis of personally oriented ideas, semantic and cognitive paradigms of education. Their nature and characteristics are considered. The units of analysis selected certain components of the paradigm, namely: mission, goals, objectives, guiding values, content of education, basic didactic tools, teacher-student relationships, criteria, functions. It is proved that the situation of confrontation and contradiction of personally oriented, semantic and cognitive paradigms of education is unacceptable, since each of them has its positives and limitations. It was found that cognitive education provides significant potential for intellectual development of the individual, it is its apparent positive. Proved that the cognitive limitations of education lies in its normative and purely social utility, which not related to the unique personality implementation, which is a passive "object" of teacher pedagogical influence; informative cognitive priority led to its content and disciplinary overload, is a serious problem of modern education in higher education institutions. Proved that priority is individually oriented paradigm associated with the formation of free, individual initiative as the "subject" of his life and this education paradigm is reflexive oriented because its values are leading self-awareness, self-development and personal fulfilment future specialist. However, objective knowledge is sometimes overlooked, and this is a certain difficulty of personally oriented education. It is found out that the benefits of the education semantic paradigm are related to the value-semantic attitude formation towards future professional activity, with updating of personal semantic experience; with semantic choice, with development of future specialist semantic potential. The reflexive nature of the personally oriented, semantic and cognitive paradigms of education is substantiated, and it is proved that the modern paradigm of higher education space will constitute a polyparadigmatic synthesis of their ideas accumulated in the education reflexive paradigm. The polyparadigmality essence is revealed as a research methodology, which is a conceptual synthesis of several existing educational paradigms.
\end{abstract}

Keywords: education paradigm, polyparadigmality, personally oriented education paradigm, semantic education paradigm, cognitive education paradigm, reflexive education paradigm.

\section{INTRODUCTION}

The development of modern society is accompanied by a transformation of its economic, political, and educational innovation sectors towards globalization and European integration, that is, a modern democratic society with European values is being built, but given the national context. These objective 
factors determine significant changes, that taking place in Ukrainian higher education system. Its modernization vector is aimed at ensuring the quality in accordance with the current European requirements for linking the education content to the demand of the labor market, to satisfy the interests and expectations of higher education applicants. The strategic positions of modern higher education in Ukraine are its axiological and human-centered priorities; competent orientation of education; realization of training on a research basis; promotion of academic mobility for all subjects of the educational process in higher education; implementation of ideas of academic integrity; interdisciplinary dimension of education; the idea implementation of andragogics for lifelong learning; soft skills development related to the critical thinking development of the individual, collaboration skills, life digitization; building of education partnership model on the basis of subject-subjective interaction between teacher and student, forming an individual educational trajectory of higher education applicants through academic mobility, non-formal education. Thus, a change of priorities of Ukrainian higher education needs to justify its new conceptual model based on a new educational paradigm. Since a particular paradigm sets the model of perception and world explanation, as well as the basis for choosing the methods of its exploration and transformation, paradigm is a fundamental principle of human interaction with the world, with others, and with himself. So paradigm space studying of modern higher education in Ukraine acquires relevance and feasibility.

The concept of "paradigm" emerged in the ancient world and comes from the Greek word " $\pi \alpha \rho \alpha \delta \varepsilon \varepsilon \gamma \mu \alpha$ ", which translates as an example, model [1, p. 193 - 194]. This concept was introduced in the modern scientific circulation by the American physics historian T. Kuhn, who interpreted the paradigm as recognized by all scientific achievements, which over a time period give to the scientific community a model of problem formulation and solution [2, p.11].

It is accepted to use such terms in pedagogy as "pedagogical paradigm"(G. Kornetov), "educational paradigm" (P. Denisenko, G. Kilyova, E. Pinchuk) or "paradigm of education" (I. Kolesnikova), "training paradigm" (I. Bech, O. Vozniuk, M. Levkivsky), or "paradigm of upbringing" (M. Rozov); "paradigm of the educational process" (N. Lavrychenko). Taking into account these conceptual variations of the paradigm phenomenon, in our study we will base on the "paradigm of education" concept introduced by I. Kolesnikova and defined by it as a conceptual model of education [3]. More detailed is the interpretation of the paradigm of education as enshrined in theoretical provisions, normative documents, traditions, human and material resources of a stable system of educational institutions activity (E. Hrykov) [4]. However, the author's interpretation of the outlined phenomenon linked to its definition as a combination of theoretical and methodological guidelines, ideas and approaches, strategies and education conceptual models that guide as a model for solving educational problems.

Thus, taking into account the starting positions, consider the paradigm of Ukrainian modern space of higher education.

\section{ANALYSIS AND DiscUSSION}

Educational paradigms have undergone a complex evolution of becoming. The dynamics of educational paradigms disclosed in detail in the A. Verbitsky studies, who identified the genesis of this educational paradigms:

- the "natural" educational paradigm of the pre-institutional period;

- the paradigm of civil education in ancient society;

- the Christian education paradigm, dogmatic type of learning in the Middle Ages;

- the classical (traditional) educational paradigm of capitalist production period;

- humanistic paradigm [5].

G. Ball modifies the latter as a rationale-humanistic paradigm [6].

Regarding the typology of educational paradigms on certain grounds most common are:

- authoritarian-imperative and humane (Sh. Amonashvili);

- cognitive and affective-emotional and volitional (or personal) (E. Yamburg) 
- scientific-technocratic, humanitarian-phenomenological and traditional pedagogical paradigms (I. Kolesnikova);

- authoritarian, manipulative and maintenance (G. Kornetov);

- reflexive (I. Kolesnikova, I. Stetsenko);

- semantic (O. Dmitrieva; I. Abakumova, P. Ermakov, I. Rudakova);

- natural science, technocratic, esoteric, humanistic and polyphonic (O. Prikot);

- functionalist, humanistic and esoteric (B. Rodionov, A. Tatur);

- integrative (O. Vozniuk, O. Dubaseniuk);

- education system paradigm (Y. Karyakin).

There is a formation of a new educational paradigm in the modern period. The idea of human and its development through education in it are reflected in the following conceptual provisions:

- human is a complex system that develops holistically;

- the main mission of higher education - ensuring the conditions for personal fulfillment;

- focus on the implementation of the requests, needs and expectations of the individual;

- subject-subjective, dialogical format of teacher and students relationships;

- focus on the competent and competitive specialist training;

- creation of academic mobility conditions for subjects of educational process in higher education;

- development of scientific potential of the individual based on the implementation of training on a research basis.

We should note that the leading feature of the education modern paradigm is its synthetic nature. Polyparadigmal integrity involves the strategic ideas of multiple educational paradigms. V. Ognevyuk argues that it is the situation of polyparadigmality in the educational space that is most favorable for the education development, since hypertrophy of one of the paradigms can adversely affect on the educational process subjects. The well-known scientist defines the current period of education in Ukraine as inter-paradigmatic [7].

Thus, taking into account the position of the theory of paradigm analysis of pedagogical reality (E. Bondarevska I. Kolesnikova), in particular, the position that the paradigm indicators of the teacher is his worldview, which determines the understanding of the personality nature and its development patterns; semantic dominant of professional being; targeted educational activities; orientation and sources of the system formation of professional and pedagogical values and criteria; the nature of the participants interaction in the pedagogical process [3], we analyze the paradigms that make up the polyparadigmatic integrity of the modern education paradigm. It should be noted that the unit of analysis chosen certain components of the paradigms, namely the mission, goals, objectives, key value, content of education, basic teaching tools, teacher and student relationship, criteria, functions.

Let us consider the essence of personality oriented education paradigm, which is the base of modern scientific and educational space and is connected with the education reorientation on the person. Its necessity and expediency grounded in methodological works of $\mathrm{N}$. Alekseev, S. Amonashvili, D. Byeluhin, V. Davidov, V. Syerykov, I. Yakymanska, who have proposed the idea of dialogue, collaboration, co-creation, individual respect.

Thus, the purpose of individually oriented education is to develop the individual as a subject of life. The main objectives - promoting personal growth of the student, namely the formation of its valuesemantic sphere, reflection, multidimensional consciousness, the ability to self-determination; organization of psychological and pedagogical support of these processes; creating a situation of free choice. The leading values of this education system are the personal dignity of everyone; freedom, creativity and individuality in the knowledge and values of self-development, self-education and selfrealization. That is, the priority of development is obvious.

According to these features individually oriented educational content aimed at its personal development and individual educational trajectory building. In this case the student recognizes the right to participate in determining the direction of education, its contents and forms of organization. In individually oriented education every student has a vector of development that does not rush from teacher to student, but rather from student to teacher. We emphasize that individually oriented 
education preferred dialogical forms of teaching and polylogue, built on the basis of equality teachers and students in the educational process. The role of the teacher is the fullest realization of requests, interests and needs, as well as taking into account individual characteristics of each student.

The relationship of teacher and student are based on humane treatment of student confidence, maintaining its identity, consistent attitude to the student as the subject of its own development. The relationships between the teacher and the student are "interpersonal" and based on the principle of equality, dialogue, coexistence, freedom, unity, acceptance.

The main criteria for the effectiveness of education are the personal growth of the student, satisfaction of his educational, spiritual, cultural and vital needs.

The key features of the personality oriented education is such as:

1) conditions creation for creative individuality self-development and revealing of personality spiritual potentialities;

2) cultivation of various forms of creative activity of the teacher and the student;

3) implementation of assistance strategy, support and respect for the student;

4) creating of conditions for free choice areas involving social and cultural values.

Personality paradigm of education is the basis for the new methodological system emergence, namely the education "semantic paradigm" (in the terminology of A. Asmolova). This process is justified because the very meaning is the basis of the organizing attitudes of the "core of the personality", the criterion component that determines the boundary of the personal, impersonal and non-personal, and in turn, meaning formation is the dominant vector of education. We have previously reported that one of the essential features of personality oriented education paradigm is the realization of the individual free choice. The person chooses in what he or she sees meaning, that is, he or she makes a "value-meaning choice" (N. Mironenkov's term). So, personal and semantic paradigm are interrelated and interdependent.

In the modern educational space of higher education institutions the ideas realization of the semantic paradigm of education is connected with the introduction of semantic pedagogy (O. Asmolov), "semantic didactics" (I. Abakumova, P. Ermakov, V. Fomenko), human education (V. Klochko).

Let us dwell on the leading features of the semantic education paradigm. Its initial idea is the provision of the subject-personal involvement of the student in the educational process by means of activation and pedagogical support of the mechanisms of meaning formation.

Thus, a leading semantic paradigm of education mission is to provide the conditions for the implementation of mechanisms of professional and personal sense. Its aim is to develop professionally significant personal meanings of the future specialist. Tasks of education semantic paradigm: realization of education value-semantic context; forming a meaningful attitude to the future profession, a meaningful setting; actualization of the student's personal semantic experience; forming the ability to express their value and meaning; development of semantic potential. The key values of this paradigm are personality, its free choice of life and professional path on the basis of certain semantic orientations. It is obvious that the priorities of the education semantic paradigm are related to the professional and personal future specialist meaning.

It should be noted that the core of the education content in the semantic paradigm is the introduction, along with the normative, integrated courses aimed at the implementation of educational meaningful context, group meaningful context, and the integration of socio-cultural context of the profession and student context and personal self-determination. That is, meaning "saturation" of education. Implementation of these educational contexts associated with the formation of "semantic field" within which there is directed broadcasting sense, of sense that initiates, directs semantic sphere of students in a particular vector in the learning process. The content of training is perceived as a personal value that has personal meaning.

In the semantic education paradigm, the meaning-oriented methods and teaching forms of dialogical orientation that initiate the meaning formation of future specialists in the educational process are leading. These include meaning-actualizing dialogue (L. Kagermazova), multicultural dialogue 
(E. Belyakova), interpersonal dialogue, polylogist. Thus, it is meaningful dialogic communication contribute to the enrichment of personal meaning through their interaction with the cultural content of personal meaning participants in the dialogue.

The relationship of teacher and student are built on the "semantic interaction" grounds, "synchronize" their semantic fields "value-semantic equality" of all the subjects of the educational process that allows everyone to exercise their choice according to their own life purport orientations. In the semantic paradigm, the teacher acts as a "facilitator" of sense actualization.

The main criteria for the training effectiveness are the value-semantic attitude to the future profession, the content of personal meanings, purport design.

The functions of meaning-oriented education are: 1) implementation of the education semantic context, the creation of conditions for a value-semantic sphere of the future specialist personality; 2) meaning "saturation" of learning content; 3) finding out the meaning-building potential of the disciplines; 4) cultivation of meaning-oriented forms of learning related to meaningful communication, as well as techniques of meaning-making of the future specialist personality.

Consequently, there is no doubt that individually oriented and semantic paradigm of education have much in common. They are interrelated and interdependent and focused on the value-semantic sphere development of the individual as "subject" of their lives. The ideas of the cognitive paradigm of education sometimes ignore in today's educational environment of higher education institutions, which is impossible because it has certain priorities that are appropriate for modern higher education. It is well known that the cognitive paradigm (imperative, traditional) links education to the cognition process through memory and certain operations of thinking. Its mission is to fulfill the social order on future specialists training with pre-defined quality of life and work. The aim of cognitive education is to develop the knowledge and skills of the educational process implementation. The main tasks of cognitive education is the development of mental abilities, formation of thinking operations necessary for the educational activities implementation. Consequently, the core values of cognitive learning are normativity and manageability.

There is natural that they are reflected in the content of cognitive education that aims to provide individual information. The subjects are a reflection of a certain science, and the educational material is a didactically interpreted scientific knowledge of universal curricula, which does not always coincide with the actual interests and needs of the student and is not his personal choice. As a result of such approaches the student is not able to use this knowledge in practice.

An obvious feature of cognitive education is the monologic forms of learning preponderance. Knowledge is transmitted as a monologue of the teacher, where he is the main acting force, leading a student who only needs to keep up with the teacher, adjust to the pace, individual characteristics and current status of the teacher. That is, there is an exaggeration of the teacher initiative, and the student has a predominantly passive role. He is the object of the mastering process a certain system of knowledge and skills and their support. It is clear that the result of this format of teaching is to build the relationship between the teacher and the student on the basis of absolute normativity on a "subjectobject basis", the teacher takes a pedagogical position "over" the student. In this communication between the teacher and the student occurs through the content, forms, methods, learning tools. At all levels of cognitive learning student is a passive "object". In this education model, the skills development of reasoned, logically correct thinking, the ability to think independently and critically, creatively and contextually, remains unaddressed. Personality training aspects confined to the formation of cognitive motivation and cognitive skills and to gain experience meaningful, valuable and emotional evaluations of their behavior and others. The task of comprehensive personality development is a "byproduct" of training activities.

Leading performance criteria are learning the knowledge, skills and abilities that define the qualitative and quantitative dimensions assimilated information.

Therefore, the leading functions of cognitive education are related to the implementation of such traditional educational functions as: 1) broadcasting of information in the form of ready knowledge and 
skills; 2) control of students' activities; 3) fixing role of the teacher as a subject of educational activities and student - as the object of his influence.

As we can see, the personal aspects of learning are minimized in the cognitive paradigm of pedagogical education.

We found that each of the described paradigm has its positives and limitations. Consider them.

Cognitive education provides significant potential for the individual intellectual development, and it is its apparent positive. However, the cognitive education limitation lies in its normativity, a purely social expediency, which is unrelated to the realization of the individual uniqueness, which is a passive "object" of the teacher pedagogical influence. That is, the direct (imperative) style of managing students' educational activity is used. The teacher and the student activities are not reflective, as traditional teaching methods do not involve the personality reflection realization. The priority of informative cognitive education has led to its substantive and disciplinary overload, which is a serious problem of modern education in higher education institutions.

The priorities of a person-centered paradigm are related to the formation of a free, initiative personality as a "subject" of one's life. This education paradigm is reflexively oriented, as its leading values are self-awareness, self-development and self-realization of the future specialist personality. The leading criterion is "personal dimension". Sometimes objective knowledge is overlooked, and this is a certain difficulty of personally-oriented education.

Semantic paradigm of education centered on the development of students personal-semantic sphere. Its advantages are connected with formation of value-semantic attitude to the future professional activity, with updating of personal semantic experience; with semantic choice, with development of semantic potential of future specialist. These personal constructs of the future specialist are reflective. Education becomes reflexively predetermined and acquires value and meaning for the individual.

Thus, given the nature of the outlined paradigms, as well as their reflexive nature, we believe that the modern paradigmatic space of higher education will be a polyparadigmatic synthesis of ideas of personally oriented, semantic and cognitive paradigms of education, which are accumulated in the reflexes. Polyparadigmality is understood as a research methodology, which is a conceptual synthesis of several existing educational paradigms.

So, consider carefully the nature of reflexive paradigm of education. It is not new. The founders of the reflexive-humanistic approach are D. Rogers, A. Maslow, I. Semenov, S. Stepanov.

Reflective paradigm of education was proposed in the 90's XX century by M. Lipman, Professor of Harvard University. Leading her thesis he considered education focus on scientific research. He saw the purpose of reflective education in "teaching young people reasonableness so that they can later become smart citizens, clever partners, smart parents" $[8, p$. 10]. The scientist focused on the development of skills of rational thinking and behavior, not on the accumulation of knowledge.

The central concept of this paradigm, according to M. Lipman, is the "community of researchers", which is an informal group of people who seek the truth in "socratic dialogue". The scientist emphasized the importance of sound reasoning and considered it serious, complex cognitive work, which involves overcoming the resistance, which manifests itself in the form of logic, fallacy of reasoning, unwillingness to compromise, disrespect for another thought [8, p.13].

M. Lipman proved the benefits of the reflexive paradigm of education. He noted that "the whole chasm lies between a situation where a student is asked a question that is known and a situation where he or she is confronted with a question that is not answered or rather controversial"[Right there, p.13]. That is, in the second case refers to the problematic situation.

Our scientific understanding of reflexive paradigm associated with the review of a synthesis of positive concepts of cognitive, personality-oriented and semantic paradigm of education.

We see the leading mission of the reflexive paradigm of education in creating a certain environment for the self-knowledge, self-awareness and self-disclosure of the future specialist personality. Its aim is to develop future professional reflective constructs, namely professional competence as reflective of significant quality and personality constructs associated with it, that is the motivation, value-semantic 
and subjective sphere. The tasks of the reflexive paradigm of education are the orientation of professional self-awareness in the direction of analysis, evaluation and correction of pedagogical concepts, own activity, perception by others, value-semantic awareness of the future profession (methodological reflection); forming the skills of grounded, reasoned, logically correct thinking (intellectual reflection); knowledge of role structure, positional organization of collective interaction with students (cooperative reflection); ideas about the other person's inner world and the causes of their actions (communicative reflection); forming an image of one's self, as well as the ability to analyze one's actions (personal reflection). The values and priorities of the reflexive paradigm are related to selfknowledge and self-awareness of the individual. It is a valid tenet that knowledge can be complete only if it is included in its assimilation of semantic structures and self-consciousness.

We emphasize that the content of reflective education aimed at creating a reflective environment within which is the formation of reflective competence as an important professional qualities of future specialist, namely: value attitude to introspection, knowledge of personal and interpersonal knowledge and skills of reflective analysis, design, modeling, individual personality development.

Teaching methods and forms that are predominantly based on one's own reflective experience, on shared reflective experience with a compulsory division of responsibilities, and on the "dialogue of reflections" of the teacher and the student are leading in the reflective paradigm of education. These are the following methods and forms of learning: analyzing your own activities as well as other people's actions in accordance with specific programs; fixation of events of own professional life; reflexive hearing; reflexively directed videos; simulation games; analysis of pedagogical situations and solving professional and pedagogical tasks.

Teacher-student relationships are built on the basis of the equality of positions of the subjects of the educational process, namely their interpersonal interaction, cooperation and co-creation, which provide for the accessibility of the teacher's experience for students and openness of students' experience for others. The position of the teacher is open until the error is acknowledged. Thus, the core of this relationship is the acceptance and empathy. In this case, the teacher acts as an assistant and consultant.

The criteria reflexive oriented education are: problematic and critical thinking, openness to dialogue, respect other opinions, empathy, flexibility in solving problems, tolerance and variation in communication, personal involvement in reflective activities.

Reflective paradigm functions are: 1) reflexive orientation of education, that is, the creation of a certain educational environment for the formation of the reflective sphere of personality of the future specialist; 2) elucidating the reflective potential of the disciplines; "reflexive saturation" of learning content; 3 ) introduction in educational process of reflective technologies that relate to the pedagogical reflection and reflective predefined constructs personality of the future specialist.

So reflexive education oriented paradigm has several obvious advantages:

-it is based on the awareness of the subjects of education of the semantic features of professional activity;

- aimed at forming a self-actualized personality, that is, the personality as the "subject" of one's life;

- can develop skills of grounded, reasoned logically correct thinking;

- creates the ability to think independently and critically.

\section{CONCLUSIONS}

Based on the analysis of personally oriented, semantic, cognitive paradigms of education, which are most widespread in the modern educational space in Ukraine, it is proved that the situation of their confrontation and negation is unacceptable, since each of them has both positives and limitations. We insist on the expediency of using in modern higher education in Ukraine positive concepts of each of these paradigms of education. That is, in our opinion, modern higher education in Ukraine should be poly-paradigmatic.

According to the provisions of modern pedagogical methodology, we understand polyparadigmality as the coexistence of several methodological systems within which a holistic model 
of the educational process is created. We argue that such a poly-paradigmatic integrity is a reflexive paradigm of education, which is a synthesis of positive concepts of cognitive, personality-oriented and semantic paradigms of education.

We see the leading mission of the reflexive education paradigm in the creation of a specific environment for the future specialist's self-awareness, self-awareness and self-disclosure; purpose - in the formation of reflective competence as a professional quality, as well as personal constructs that are associated with it, namely: the motivational, value-meaning and subject area of the future specialist.

Analytical review of these paradigms of education made it possible to ensure that the different paradigms not interpret reality in a new way. They interpret the same phenomenon it somehow transformed and detailed under certain scientific approaches. We understand the scientific approach as a way of conceptualizing knowledge, defined certain idea, concept and based on several basic categories. We believe that the poly-paradigm of modern education correlates with its poly-suitability. This aspect of the study will be grounded in the following scientific exploration.

\section{REFERENCES}

[1] Ogurtsov A.P. Paradigm. In: New Philosophical Encyclopedia: in 4 vol., 3. Mysl, Moskow, 2001, 193-194. (in Russian)

[2] Kuhn T. The structure of scientific revolutions. AST, Moskow, 2003. (in Russian)

[3] Kolesnikova I.A. Pedagogical reality: the experience of inter-paradigmatic reflection. Detstvo-press, St. Petersburg, 2001. (in Russian)

[4] Hrykov E. Pedagogical Science in Ukraine: State and Development Directions. Shliakh Osvity, 4 (2003). (in Ukrainian)

[5] Verbitsky A.A. New educational paradigm and contextual learning. Research Center for Problems of the Specialists Training Quality, Moskow, 1999. (in Russian)

[6] Ognevyuk V.O. Inter-paradigm Period of Education. Nova paradigma, 50 (2005), 36-48. (in Ukrainian)

[7] Lipman M. Thinking in Education. Cambridge University press, Cambridge, 1991.

Address: Viktoriya Zhelanova, Borys Grinchenko Kyiv University, 18/2, Bulvarno-Kudriavska Str., Kyiv, 04053, Ukraine.

E-mail: vic.zhelanova@gmail.com

Received: 20.01.2020; revised: 06.03.2020.

Желанова Вікторія. Парадигмальний простір сучасної вищої освіти в Україні. Журнал Прикарпатського університету імені Василя Стефаника, 7 (1) (2020), 32-40.

У статті проаналізовано парадигмальний простір вищої освіти в Україні. Доведено, що сучасна парадигма освіти має синтетичний характер, базується на принципі поліпарадигмальності і $є$ синтезом ідей особистісно зорієнтованої, смислової та когнітивної парадигм освіти. Розгдянуто їх сутність та особливості. Одиницями аналізу обрано певні компоненти парадигм, а саме: місія, цілі, завдання, провідні цінності, зміст освіти, основні дидактичні засоби, взаємини викдадача й студента, критерії, функції. Доведено, що ситуація протистояння та взаємозаперечення особистісно зорієнтованої, смислової та когнітивної парадигм освіти є неприпустимою, оскільки кожна з них має 
свої позитиви і обмеження. 3'ясовано, що когнітивна освіта містить значний потенціал щодо інтелектуального розвитку особистості, це е ії очевидним позитивом. Обгрунтовано, що обмеженість когнітивної освіти полягає в іï нормативності, суто соціальній доцільності, яка не пов'язана 3 реалізацією унікальності особистості, що е пасивним “об'єктом" педагогічного впливу викладача; пріоритетність інформативності когнітивної освіти призвела до їі змістовного та дисциплінарного перевантаження, що є серйозною проблемою сучасної освіти в ЗВО. Доведено, що пріоритети ж особистісно зорієнтованої парадигми пов'язані з формуванням вільної, ініціативної особистості як “суб'єкта" свого життя й ця парадигма освіти є рефлексивно орієнтованою, оскільки провідними ії цінностями є самоусвідомлення, саморозвиток та самореалізація особистості майбутнього фахівця. Проте інколи поза увагою залишається об'єктивне знання, і це є певною складністю особистісно зорієнтованої освіти. 3'ясовано, що переваги смислова парадигма освіти пов'язані 3 формуванням ціннісно-смислового ставлення до майбутньої професійної діяльності, з актуалізацією особистісного смислового досвіду; зі смисловим вибором, з розвитком смислового потенціалу майбутнього фахівця. Обгрунтована рефлексивна природа особистісно зорієнтованої, смислової та когнітивної парадигм освіти й доведено, що сучасний парадигмальний простір вищої освіти буде складати поліпарадигмальний синтез їх ідей, що акумудюються в рефлексивній парадигмі освіти. Розкрито сутність поліпарадигмальності як дослідницьку методологію, що є концептуальним синтезом кількох існуючих освітніх парадигм.

Ключові слова: парадигма освіти, поліпарадигмальність, особистосно зорієнтована парадигма освіти, смислова парадигма освіти, когнітивна парадигма освіти, рефлексивна парадигма освіти. 